\title{
Origin of Depleted Cratonic Harzburgite by Deep Fractional Melt Extraction and Shallow Olivine Cumulate Infusion
}

\author{
Kinzler, R.J. ${ }^{1}$ and Grove, T.L. ${ }^{2}$
}

1. Department of Earth and Planetary Sciences, American Museum of Natural History, Central Park West at 79th Street, New York, New York 10024-5192 USA

2. Department of Earth, Atmospheric and Planetary Sciences, Massachusetts Institute of Technology, Cambridge, MA 02139 USA

We have used the near-fractional adiabatic decompression melting model developed by Kinzler (1997) to evaluate potential melting mechanisms that could account for the observed enstatite-rich and high $\mathrm{Mg \#}$ characteristics of cratonic peridotites. Our model consists of a three-step process. 1) Near-fractional decompression melting of a fertile peridotite protolith at pressures between 3.5 and 1.6 $\mathrm{GPa}$ produces a residue that coincides with the enstatite-rich extreme of the cratonic peridotite array. This end member represents the point in fractional melting where high-Ca pyroxene (hi-Ca pyx) is exhausted from the residue. 2) Further decompression melting of the olivine + orthopyroxene (opx) + garnet residue leads to a depletion in opx and garnet and enrichment in olivine. 3) As this depleted residue ascends to shallow depths, it cools to below-solidus temperatures and ceases to melt. Magmas continuously produced in the deeper part of the melt column ascend into this shallow, cool depleted residue and crystallize liquidus olivine. This process infuses a continuum of variably depleted residues produced during step 1 and 2 with olivine and lowers their bulk compatible trace element abundances. In the following discussion we predict the compositional variations that occur from such a three-step process and compare them to the chemical characteristics of Kaapvaal and Siberian depleted harzburgites.

Near-fractional melting in the upper spinel- and garnet- facies O'Hara (1963) showed that peridotite melting in the garnet stability field proceeded through the following reaction:

$$
\text { olivine + garnet }+ \text { high-Ca pyx }=\text { liquid }+ \text { opx } \quad[1]
$$

Kinzler (1997) found that peridotite melting in the spinel stability field at pressures approaching the spinel to garnet transition also proceeded through an opx-producing reaction:

$$
\text { olivine }+ \text { spinel }+ \text { high-Ca pyx }=\text { liquid }+ \text { opx }
$$

Kinzler (1997) also found that melting in the transition region (where spinel and garnet coexist) proceeded through an opx-producing reaction. The minimum pressure under which the form of melting reaction resembles that shown in [1] is $\sim 2.1 \mathrm{GPa}$ for natural depleted mantle bulk compositions; that shown in [2] persists to pressures as low as $1.7 \mathrm{GPa}$ (and potentially lower pressures for alkali-rich melts). We have used the stoichiometric coefficients provided by Kinzler (1997) to quantitatively assess the role of near-fractional, adiabatic decompression melting in the formation of the Kaapvaal peridotites. The Hart and Zindler depleted mantle 1 (Kinzler, 1997) was chosen as the starting mantle composition, and changes in the initial mantle are not expected to significantly alter the conclusions. For the purposes of this discussion we modeled step 1 of melt production over the shallowest portion of the pressure interval where opx + melt are produced. Near fractional-melting was assumed to occur at the rate of $1 \mathrm{wt} . \%$ melting per $0.1 \mathrm{GPa}$ of ascent. Of this $1 \%$ melt, $90 \%$ was removed and $10 \%$ left in the residue. Melting proceeded until all highCa pyx was exhausted. The end point of the step 1 melting process is shown in Fig. 1 as a gray square. Note that this composition plots at the opx-rich end of the harzburgite suite of Boyd et al. (1997). This is a result not anticipated by Herzberg (1993, and references therein). Their treatment 
of mantle melting assumed a batch process, and they concluded that the $\mathrm{SiO}_{2}$ content of any likely melt was too high to produce an $\mathrm{SiO}_{2}$-rich harzburgite residue from a low-SiO${ }_{2}$ starting mantle. Their analysis neglected the incongruent nature of the mantle melting reaction. With opx on the melt producing side of [1] or [2], fractional melting leads to $\mathrm{SiO}_{2}$-enrichment of the residue through the addition of opx, and the extraction of $\mathrm{SiO}_{2}$-undersaturated melts. This melting process contrasts with the one that leads to the production of abyssal peridotites at mid-ocean ridges (Niu et al., 1998). Melting of the mantle beneath mid-ocean ridges to produce MORB begins at lower pressures, and most of the melt generation occurs at pressures where incongruent melting yields olivine + opx + liquid or olivine + liquid as products.

Melting after exhaustion of high-Ca pyx and infusion of olivine by shallow fractional crystallization After all the high-Ca pyx is extracted from the residue, melting will cease to proceed by reaction [1] or [2]. We have inferred a melting reaction along the olivine + opx + garnet boundary from high-extent melting experiments (Takahashi, 1986) to be: olivine + opx + garnet $=$ liquid. Melting under these conditions leads to a slight enrichment of olivine and an increase in the $\mathrm{Mg} \#$ of the residue. The path followed by the residue during this stage of melting (step 2) is shown in Fig. 1 as a light gray dashed arrow. For step 3, we assume that the mantle falls below its solidus as it ascends to shallower depth and that melt generation therefore ceases. Magmas produced deeper in the mantle melting column will move up through this shallow residue and crystallize olivine as they cool and decompress. Such a process naturally leads to continued enrichment of the residue in olivine. The step 3 infusion of olivine by fractional crystallization is illustrated in Fig. 1 for the least- (step 1) and most-depleted (step 2) mantle residues. We suggest that step 3 would impart a general olivine enrichment trend to the melting residues produced through steps 1 and 2 . This process also results in a decrease in compatible elements in the residue as the fraction of olivine increases, because the magmas that precipitate the olivine are continuously cooling and fractionating as they ascend through the overlying residues. This step of the process could include dissolution of opx with precipitation of olivine from the infiltrating magma (e.g. Keleman [1990] where olivine rather than opx [Keleman et al., 1997] is produced by melt/rock reaction). Olivine that is added will have a lower $\mathrm{Ni}$ content, but it is not clear that the step 3 magmatic process proposed here will be capable of producing the $\mathrm{Ni}$ trends observed in some Kaapvaal suites (Boyd, 1997).

Summary We have calculated a near-fractional, adiabatic decompression melting model that can lead to opx-enrichment in a mantle residue. The correspondence between the model calculation and the cratonic peridotite suite is promising, but it does not constitute a perfect match. The Kaapvaal suite samples are variably serpentinized, and this serpentinization process may have modified the olivine composition and other bulk rock chemical characteristics, like the Ni content. Finally, the conditions of melting will have an effect on the ultimate position of the opx enriched residue. The Kinzler (1997) data encompass the low-pressure end of the potential melting regime where reaction [1] and [2] may occur. Higher pressure models should be explored. In addition, the influence of $\mathrm{H}_{2} \mathrm{O}$, which can also result in the melting stoichiometry expressed in [2] (Gaetani and Grove, 1998) should be explored. Boyd (1989) first pointed out the contrast between major element characteristics of depleted cratonic harzburgites and abyssal peridotites. The combined processes of melting and subsequent olivine addition proposed here for the generation of the Kaapvaal peridotites is similar to that proposed by Niu et al. (1998) to explain the generally olivine-rich nature of abyssal peridotites. The key difference is the pressure at which the two processes are thought to occur. 


\section{References}

Boyd, F.R., 1997, Correlation of orthopyroxene abundance with Ni content of coexisting olivine in cratonic peridotites: EOS, 78, p. F746.

Boyd, F.R., 1989, Compositional distinction between oceanic and cratonic lithosphere: Earth Planet. Sci. Lett. 96, p. 15-26.

Boyd, F.R., Pokhilenko, N.P., Pearson, D.G., Mertzman, S.A., Sobolev, N.V. and Finger, L.W., 1997, Composition of the Siberian cratonic mantle: evidence from Udachnaya peridotite xenoliths: Contrib. Mineral. Petrol., 128, p. 228-247.

Herzberg, C.T., 1993, Lithospheric peridotites of the Kaapvaal craton: Earth Planet. Sci. Lett. 120, p. 13-29.

Gaetani G.A. and Grove, T.L., 1998, The influence of water on melting of mantle peridotite: contrib. Mineral. Petrol., in press.

Keleman, P.B., 1990, Reaction between ultramafic rock and fractionating basaltic magma I: Phase relations, the origin of calc-alkaline magma series and the formation of discordant dunite: J. Petrol., 31, p. 51-98.

Keleman, P.B., Bernstein, S., and Hart, S.R., 1997, $\mathrm{SiO}_{2}$ addition to cratonic mantle via melt/rock reactions above subduction zones: EOS, 78, p. F747.

Kinzler, R.J., 1997, Melting of mantle peridotite at pressures approaching the spinel to garnet transition: Application to mid-ocean ridge basalt petrogenesis: J Geophys Res, 102, p. 853-874. O'Hara, M.J., 1963, Melting of garnet peridotite at 30 kilobars: Carnegie Inst. of Wash Yrbk, 62, p.71-76.

Niu, Y.-L, Langmuir, C.H., and Kinzler, R.J., 1998, The origin of abyssal peridotites: a new perspective Earth Planet. Sci. Lett., 152, p. 251-265.

Takahashi, E., 1986, Melting of a dry peridotite KLB-1 up to $14 \mathrm{GPa}$ : Implications on the origin of peridotitic upper mantle: J Geophys Res, 91, p. 9367-9382.

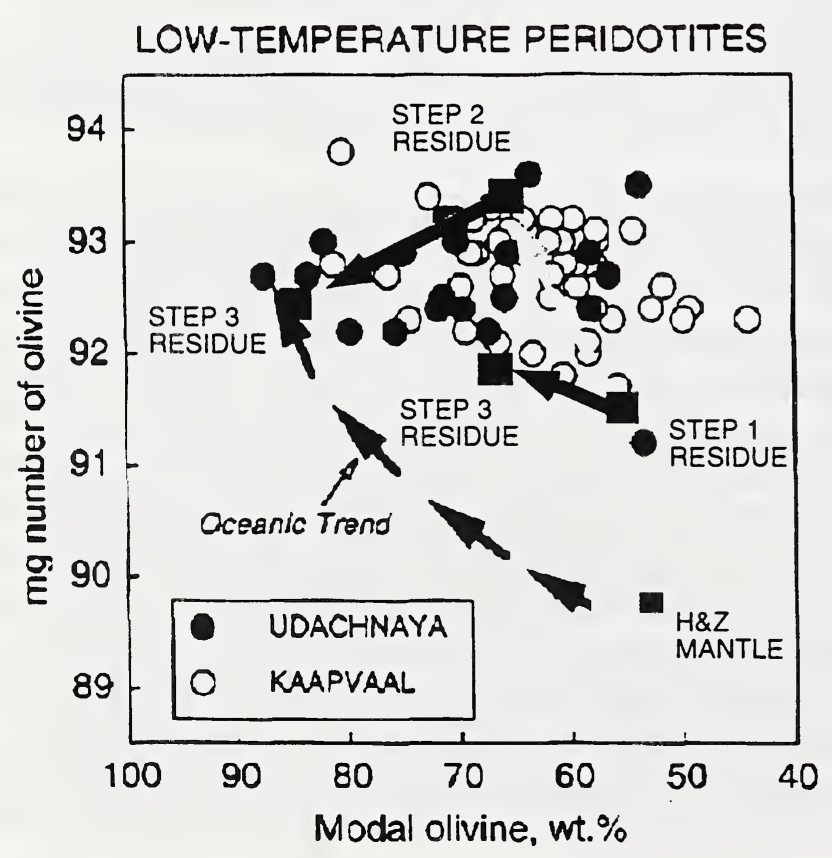

Fig. 1 A plot of modal olivine (wt. $\%$ ) vs $\mathrm{Mg \#} \mathrm{(mole} \mathrm{\% )} \mathrm{for} \mathrm{low}$ temperature peridotites from the Kaapvaal and Siberian cratons from Boyd et al. (1997). Superimposed on this plot is the fractional melting and olivine infusion model. Fractional melting in steps 1 and 2 produces a variably depleted melting column. In step 3 magmas from depth ascend and pass through the residue, where they decompress, cool and crystallize liquidusolivine. 